\title{
KARAKTERISTIK KATARAK KONGENITAL DI RSUD PROVINSI NTB PERIODE 2018-2019
}

\author{
Rani Salsabilla, Marie Yuni Andari, Monalisa Nasrul \\ Fakultas Kedokteran, Universitas Mataram, Indonesia \\ Email: ranisalsabilla20@gmail.com marieyuni79@yahoo.co.id \\ doktermona@yahoo.com
}

\begin{abstract}
Abstrak
Katarak kongenital merupakan penyebab kebutaan utama pada anak-anak. Kekeruhan lensa pada usia awal kehidupan berpotensi mengakibatkan gangguan penglihatan permanen bila tidak ditatalaksana dengan segera. Operasi katarak yang dilakukan pada waktu yang tepat dapat menghindarkan anak dari amblyopia (mata malas). Penelitian ini bertujuan untuk mengetahui karakteristik katarak kongenital di RSUD Provinsi NTB Periode 2018-2019. Penelitian ini menggunakan metode penelitian deskriptif. Data yang digunakan adalah data sekunder dari rekam medis pasien katarak kongenital di RSUD Provinsi NTB pada periode 2018-2019. Pada periode 2018-2019, terdapat 40 anak yang mengalami katarak kongenital. Sebagian besar penderita katarak kadalah perempuan (52.5\%), bertempat tinggal di luar kota Mataram (92.5\%) dengan sebaran usia di bawah 12 bulan (95\%) dan sisanya di atas 12 bulan. Pada bayi di bawah 12 bulan, 53\% diantaranya terdiagnosis saat berusia 1-2 bulan. Karakteristik katarak kongenital yang ditemukan adalah umumnya bilateral (52.5\%), memiliki berat badan lahir normal (52.5\%), riwayat persalinan normal $(67.5 \%)$ dan memiliki kelainan kongenital lain ekstraokular (72.5\%). Penderita katarak kongenital di RSUD Provinsi NTB sebagian besar terdiagnosis pada usia cukup dini yaitu 1-2 bulan pada awal kehidupannya sehingga dengan terapi yang tepat dan cepat diharapkan bisa mengurangi risiko amblyopia.
\end{abstract}

Kata Kunci: Katarak kongenital; karakteristik; Nusa Tenggara Barat

\section{Abstract}

Congenital cataracts are the leading cause of blindness in children. Lens opacity in early life has the potential to cause permanent visual impairment if not treated promptly. Cataract surgery performed at the right time can prevent children from amblyopia (lazy eye). This study aims to determine the characteristics of congenital cataracts at the West Nusa Tenggara Provincial General Hospital in the 2018-2019 period. This research uses descriptive method. The data used is secondary data from medical records of congenital cataract patients at the West 
Nusa Tenggara Provincial General Hospital in the 2018-2019 period. In the 2018-2019 period, 40 children had congenital cataracts. Most of the cataract sufferers were women (52.5\%); living outside the city of Mataram (92.5\%) with an age distribution of under 12 months (95\%) and the rest over 12 months. For infants under 12 months, 53 percent have been diagnosing at the age of 1-2 months. The characteristics of congenital cataracts found were generally bilateral (52.5\%), had standard birth weight (52.5\%), history of natural birth delivery (67.5\%), and had other extraocular congenital abnormalities (72.5\%). Most patients with congenital cataracts in the West Nusa Tenggara Provincial General Hospital have been diagnosing at a (pretty/moderately) early age of 1-2 months at the beginning of their lives. So, with appropriate and prompt therapy, hoping that it can reduce the risk of amblyopia.

Keyword: congenital cataract, characteristic, West Nusa Tenggara

Diterima: 15-11-2021 Direvisi: 10-12-2021_ Diterbitkan: 20-12-2021

\section{Pendahuluan}

Katarak adalah suatu kondisi kekeruhan pada lensa yang dapat terjadi akibat hidrasi (penambahan cairan) lensa, denaturasi protein lensa terjadi akibat kedua-duanya (Ilyas, 2006). Sekitar 180 juta orang di seluruh dunia mengalami keterbatasan penglihatan, 40 sampai 45 juta di antaranya mengalami kebutaan akibat katarak dan sepertiga dari jumlah tersebut merupakan penduduk Asia Tenggara. Prevalensi katarak di Nusa Tenggara Barat sekitar 1,6\% dengan prevalensi nasional sekitar 1,8 \%. Jumlah ini diperkirakan akan meningkat seiring dengan pertambahan penduduk yang pesat dan meningkatnya usia harapan hidup di Indonesia ( $\mathrm{Ri}, 2013$ ). Inilah penyebab utama kebutaan di seluruh dunia (Organization, 2012).

Katarak kongenital merupakan kekeruhan lensa yang terlihat pada anak sejak dari lahir (Ilyas, 2006). Orang tua akan melihat ada bercak putih (seperti awan) pada mata anak untuk pertama kali, dan tergantung derajat katarak yang dialami anak tersebut (HK, 2013). Prevalensi global katarak kongenital di negara berkembang mencapai 1-15 per 10.000 anak, dan prevalensi katarak kongenital di negara berkembang 10 kali lipat dari negara maju (Lin et al., 2015). Katarak kongenital merupakan penyebab utama kebutaan pada anak. Sekitar 200.000 anak di seluruh dunia mengalami kebutaan karena katarak kongenital, di mana 133.000 di antaranya adalah penduduk negara berkembang (Rajavi et al., 2015). Kebutaan pada anak tersebut akan berdampak negatif akibat gangguan penglihatan di kemudian hari, sehingga menurunkan kualitas hidup pasien, menurunkan status sosial, dan meningkatkan morbiditas dan mortalitas (Finger et al., 2012).

Kebutaan akibat katarak akan terus meningkat karena orangtua penderita tidak menyadari bahwa penglihatan baru terpengaruh setelah katarak berkembang sekitar 3-5 tahun dan menyadari penyakit ini setelah memasuki stadium kritis. Hal ini disebabkan kurangnya pengetahuan tentang gejala katarak. Salah satu penyebab tingginya angka 
kebutaan akibat katarak adalah kurangnya perhatian masyarakat terhadap kesehatan mata (Irawan et al., 2015).

Berdasarkan penjelasan diatas, peneliti tertarik untuk melakukan penelitian mengenai karakteristik katarak kongenital di RSUD Provinsi NTB pada periode 20182019.

\section{Metode Penelitian}

Penelitian ini menggunakan metode penelitian deskriptif dengan menggunakan desain penelitian potong silang. Penelitian ini dilakukan dengan menggunakan data rekam medik pasien katarak kongenital di RSUD Provinsi NTB pada periode Januari 2018-Desember 2019 yang diambil satu kali. Penelitian dilaksanakan di RSUD Provinsi NTB pada bulan Januari-April 2021. Kriteria inklusi adalah semua pasien yang di diagnosis katarak kongenital di poli mata RSUD Provinsi NTB. Pada penelitian ini menggunakan teknik total sampling dimana menggunakan data rekam medik seluruh populasi pasien katarak kongenital di RSUD Provinsi NTB pada periode penelitian. Sebelum pengambilan data, dilakukan uji etik di RSUD Provinsi NTB. Data rekam medik yang dicatat adalah usia, jenis kelamin, lateralitas, tempat tinggal, berat badan lahir, cara lahir, dan kelainan kongenital lainnya (Dewi et al., 2019).

\section{Hasil dan Pembahasan}

\section{A. Hasil Penelitian}

Subjek penelitian dalam penelitian ini adalah pasien RSUD Provinsi NTB yang terdiagnosis katarak kongenital. Berikut tabel jumlah subjek penelitian ditinjau dari usia, jenis kelamin, lateralitas, wilayah tempat tinggal, berat badan lahir, cara lahir, dan kelainan kongenital lainnya.

Tabel 1. Distribusi Karakteristik Katarak Kongenital

\begin{tabular}{rcc}
\hline \multicolumn{1}{c}{ Karakterisik Pasien } & Frekuensi & Presentase (\%) \\
\hline Usia & & \\
$1 . \leq 12$ bulan & 38 & 95 \\
$-\quad 0-2$ bulan & 21 & 53 \\
$-\quad 3-6$ bulan & 12 & 30 \\
$-\quad 6-12$ bulan & 5 & 13 \\
2. $>12$ bulan & 2 & 5 \\
\hline Jenis Kelamin & & \\
1. Laki - laki & 19 & 47,5 \\
2. Perempuan & 21 & 52,5 \\
\hline Lateralitas & & \\
1. Unilateral & 19 & 47,5 \\
2. Bilateral & 21 & 52,5 \\
\hline Wilayah Tempat Tinggal & & \\
1. Mataram & 3 & 7.5 \\
2. Luar Mataram & 37 & 92.5 \\
\hline
\end{tabular}




\begin{tabular}{|c|c|c|c|}
\hline & - $\quad$ Lobar & 4 & 10 \\
\hline & - Loteng & 8 & 20 \\
\hline & - $\quad$ KLU & 2 & 5 \\
\hline & - Lotim & 12 & 30 \\
\hline & - Sumbawa & 3 & 8 \\
\hline & - Bima & 7 & 18 \\
\hline & - $\quad$ Dompu & 1 & 3 \\
\hline \multicolumn{4}{|c|}{ Berat Badan Lahir } \\
\hline 1. & BBLR & 14 & 35.0 \\
\hline 2. & Tidak BBLR & 21 & 52.5 \\
\hline 3. & Tidak ada data & 5 & 12.5 \\
\hline \multicolumn{4}{|c|}{ Cara Lahir } \\
\hline 1. & Tidak SC & 27 & 67.5 \\
\hline 2. & $\mathrm{SC}$ & 8 & 20.0 \\
\hline 3. & Tidak ada data & 5 & 12.5 \\
\hline \multicolumn{4}{|c|}{ Kelainan Kongenital Lain } \\
\hline & Intraokular & 9 & 22.5 \\
\hline & - Retinoblastoma & 2 & 5 \\
\hline & - $\quad$ Katarak Pada Orang Tua & 7 & 18 \\
\hline & Ekstraokular & 29 & 72.5 \\
\hline & - $\quad$ TORCH & 15 & 38 \\
\hline & - $\quad$ Down Syndrome & 6 & 15 \\
\hline & - Kelainan Jantung Bawaan & 5 & 13 \\
\hline & - $\quad$ Kelainan di Bagian Tubuh Lain & 3 & 8 \\
\hline 3. & $\begin{array}{l}\text { Tidak disertai kelainan kongenital } \\
\text { lainnya }\end{array}$ & 2 & 5.0 \\
\hline
\end{tabular}

Berdasarkan penelitian ditemukan bahwa lebih banyak responden yang berusia kurang dari atau sama dengan 12 bulan, yaitu 38 orang atau 95\% diantaranya yaitu berusia 0-2 bulan sebanyak 21 orang $(53 \%)$. Berdasarkan jenis kelamin lebih banyak pada perempuan, yaitu sebanyak 21 orang atau $52,5 \%$. Untuk mata yang terkena lebih sering terjadi pada kedua mata (bilateral) yaitu sebanyak 21 orang atau 52,5\%. Tempat tinggal pasien katarak kongenital mayoritas berada di luar Mataram yaitu sebanyak 37 orang atau 92,5\% diantaranya yang terbanyak yaitu dari Lotim sebanyak 12 orang (30\%). Berdasarkan berat badan lahir di dapatkan lebih banyak tidak BBLR yaitu sebanyak 21 orang $(52,5 \%)$ dengan cara lahir yaitu lebih banyak pada yang tidak SC 27 orang $(67.5 \%)$. Berdasarkan kelainan kongenital lain lebih banyak ditemukan yang ekstraokular yaitu 29 orang $(72.5 \%)$ dengan kelainan terbanyak adalah TORCH dengan jumlah 15 kasus (38\%).

\section{B. Pembahasan}


Katarak kongenital merupakan penyebab penting dari gangguan penglihatan pada anak. Tatalaksana dan skrining yang cepat dapat mencapai hasil visual yang optimal. Pada penelitian ini karakteristik yang dimaksud meliputi, usia anak saat didiagnosis, jenis kelamin, lateralitas, wilayah tempat tinggal, berat badan lahir, cara lahir, dan kelainan kongenital lainnya pada tahun 2018 sampai 2019 di RSUD Provinsi NTB.

\section{Pembahasan Karakteristik Individu Berdasarkan Usia}

Penelitian ini menunjukkan bahwa lebih banyak responden yang berusia di bawah 12 bulan, yaitu 38 orang atau 95\%. Dimana usia terbanyak yaitu pada usia 0 sampai 2 bulan yaitu 21 orang (53\%), usia 3 sampai 6 bulan yaitu 12 orang (30\%), dan usia 6 sampai 12 bulan 5 orang (13\%). Sedangkan responden yang berusia lebih dari 12 bulan sebanyak 2 orang atau 5\%. Hal ini menunjukkan bahwa skrining dan tatalaksana dilakukan lebih awal sehingga terjadinya komplikasi minimal dan prognosis diharapkan akan lebih baik. Hasil ini serupa dengan penelitian yang dilakukan pada tahun 2016 di Medan yang mendapatkan bahwa pasien yang saat didiagnosis berada pada usia 0 sampai 12 bulan adalah sebanyak 15 orang $(57,6 \%)$, usia $13-23$ bulan sebanyak 3 orang $(9,1 \%)$, usia 2-5 tahun sebanyak 5 orang $(15,2 \%)$, usia 6-11 tahun sebanyak 4 orang $(12,1 \%)$ dan usia 12-18 tahun sebanyak 2 orang $(6,1 \%)$ (Khotimah \& Sutyawan, n.d.).

Usia pada penderita katarak kongenital juga menjadi faktor penting dalam hal keberhasilan pengobatan dimana aktivitas anak semakin meningkat bersamaan dengan daya kerja mata yang juga terus bertambah. Selain itu yang menjadi salah satu penyebab adalah kemungkinan keterlambatan diagnosis yang kemungkinan kurang mengertinya orangtua mengenai dampak jangka panjang yang diakibatkan oleh katarak terhadap penglihatan anak yang berakibat keterlambatan dalam mendapatkan tatalaksana yang tepat dan dapat berakhir dengan kebutaan pada anak (Reddy et al., 2009).

Oleh sebab itu, diagnosis dini serta rujukan menjadi faktor penting dalam mendapatkan prognosis yang baik. Jika terjadi keterlambatan usia operasi maka dapat memperburuk prognosis, hal ini disebabkan karena timbulnya kelainan mata lainnya pada penderita katarak kongenital, diantaranya ambliopia, strabismus, dan nystagmus (Golozar et al., 2018).

\section{Pembahasan Karakteristik Individu Berdasarkan Jenis Kelamin}

Pada penelitian ini katarak kongenital lebih sering pada anak dengan jenis kelamin perempuan, yaitu sebanyak 21 orang atau 52,5\%, sedangkan responden yang berjenis kelamin laki-laki sebanyak 19 orang atau 47,5\%. Hal ini seperti yang terjadi pada penelitian Bhatti (2003) yang menyatakan bahwa kejadian katarak kongenital secara keseluruhan pada anak perempuan lebih tinggi, yaitu 2,06 per 10.000 kelahiran dibandingkan pada anak laki-laki, yaitu 1,95 per 10.000 kelahiran (Bhatti et al., 2003).

Meskipun secara umum, tidak ada predileksi jenis kelamin khusus terhadap kejadian katarak pada anak-anak, akan tetapi perbedaan angka prevalensi tersebut diamati untuk menghubungkan dengan ekspektasi sosial terhadap peran anak laki-laki dalam masyarakat dibandingkan dengan alasan biologis (HK, 2013). Penelitian Marzieh dkk mengatakan dalam penelitiannya bahwa hal ini disebabkan pola perawatan yang berbeda pada perempuan dibandingkan laki-laki di negara berkembang. Akan tetapi, perbedaan 
jenis kelamin tidak memiliki hubungan yang signifikan dengan perbaikan visus pada pasien katarak anak yang telah dioperasi (Katibeh et al., 2013).

\section{Pembahasan Karakteristik Individu Berdasarkan Lateralitas}

Penelitian ini mendapatkan temuan bahwa berdasarkan lateralitas katarak kongenital, didapatkan bahwa lebih sering terjadi pada kedua mata (bilateral) yaitu sebanyak 21 orang atau 52,5\%, sedangkan yang terjadi pada satu mata (unilateral) sebanyak 19 orang atau 47,5\%. Hal ini dapat dihubungkan dengan teori yang mengungkapkan bahwa penderita katarak kongenital harus menjalani pembedahan secepatnya, karena banyaknya kelainan mata lain yang dapat timbul sehingga mempengaruhi prognosis nantinya.

Katarak kongenital unilateral sebaiknya dioperasi lebih cepat dibanding katarak bilateral. Untuk mencapai hasil seoptimal mungkin, sebaiknya katarak kongenital bilateral dioperasi sebelum usia 6-10 minggu, dan katarak kongenital unilateral dioperasi lebih cepat lagi, yaitu sesegera mungkin (dalam hitungan hari) setelah kelahiran hingga sebelum usia 6 minggu (Alipour et al., 2012). Oleh karena itu, pada penelitian ini yang unilateral lebih sedikit dikarenakan sudah mendapat tatalaksana lebih cepat dibandingkan yang bilateral dan prognosis tidak lebih buruk. Hal ini didukung oleh penelitian di Nepal pada tahun 2014 menemukan frekuensi katarak kongenital bilateral $(78,2 \%)$ lebih banyak dari pada unilateral $(21,8 \%)$ (Sharma et al., 2014).

\section{Pembahasan Karakteristik Individu Berdasarkan Wilayah Tempat Tinggal}

Penelitian ini ditemukan kasus katarak kongenital lebih banyak ditemukan dari luar Mataram yaitu sebanyak 37 orang atau 92,5\%, sedangkan yang berasal dari Mataram sebanyak 3 orang atau 7,5\%. Wilayah luar kota Mataram yang terbanyak ada di daerah Lombok Timur yaitu 12 orang (30\%), Lombok Tengah yaitu 8 orang (20\%), dan Bima yaitu 7 orang (18\%). Hal ini dikarenakan jauh dari daerah perkotaan, fasilitas kesehatan di daerah tersebut juga kurang memadai sehingga pasien perlu dirujuk kefasilitias kesehatan yang lebih lengkap untuk mendapatka informasi dan tatalaksana lebih lanjut. Kemudian Ante Natal Care (ANC) saat kehamilan ibu juga masih sangat kurang sehingga ibu tidak mengetahui apa saja kelainan yang dialami saat kehamilan, sehingga hal ini yang menyebabbkan daerah Lombok Timur, Lombok Tengah, dan Bima ini memiliki angka kejadian katarak kongenital yang banyak tiap tahunnya.

Suatu daerah disebut perkotaan apabila mempunyai ciri-ciri seperti kepadatan penduduk yang tinggi, fasilitas dalam berbagai hal tercukupi, serta fasilitas kesehatan yang cukup lengkap. Masyarakat juga mudah mendapatkan informasi mengenai kesehatan yang bisa didapatkan dari perangkat elektronik dan lainnya sehingga dapat meningkatkan kesadaran dan pemahaman masyarakat terkait dengan kesehatan serta dapat sesegera mungkin untuk dilakukan pemeriksaan di fasilitas kesehatan yang lengkap. Sedangkan, suatu daerah disebut pedesaan apabila kepadatan penduduknya rendah, mata pencarian sebagian besar penduduknya di bidang pertanian, serta fasilitas pelayanan umum dan kesehatan yang kurang lengkap. Kesadaran dan pemahaman yang masih relatif rendah tentang pentingnya deteksi dini dan pencegahan suatu penyakit ini juga masih sangat kurang. Hal ini seringkali menyebabkan keterlambatan operasi yang 
dipengaruhi tiga hal, yaitu pemahaman orangtua terhadap katarak pada anaknya, kondisi akses menuju pelayanan kesehatan, dan persetujuan untuk menjalani operasi (Mwende et al., 2005).

Tempat tinggal juga memiliki kaitan dengan sinar UV yang merupakan faktor resiko orang tua. Jika orang tua bekerja dibawah paparan sinar UV maka memiliki resiko terjadinya katarak sehingga perlu ditelusuri terkait riwayat keluarga karena sekitar sepertiga katarak kongenital ini merupakan herediter. Seringnya terpapar sinar UV-B di daerah tropis akan mengakibatkan kerusakan pada kornea dan lensa mata, selain itu sinar UV-A juga dapat mengganggu fungsi saraf penglihatan (Ri, 2013).

\section{Pembahasan Karakteristik Individu Berdasarkan Berat Badan Lahir}

Dalam penelitian ini didapatkan pasien dengan yang tidak BBLR yaitu sebanyak 21 orang atau 52,5\%, kemudian responden BBLR sebanyak 14 orang atau 35,0\%. Sedangkan yang tidak ada data sebanyak 5 orang atau 12,5\%. Pada data yang tidak memiliki informasi terkait cara lahir, maka data tersebut tidak dapat dilakukan analisis lebih lanjut. Hal ini berbeda dengan penelitian yang dilakukan oleh San Giovanni (2002) bayi yang lahir dengan berat $\leq 2500$ gram memiliki risiko katarak 3-4 kali lipat dibandingkan bayi yang lahir dengan berat badan normal. Berdasarkan penelitian lain yang dilakukan di Indonesia oleh Sutyawan (2017) bahwa berat badan lahir rendah berkaitan dengan kejadian katarak kongenital idiopatik bilateral (Khotimah \& Sutyawan, n.d.).

Penyebab lain yang dapat mempengaruhi terjadinya anak lahir dengan berat badan lahir rendah yaitu kurangnya asam folat pada trimester pertama dapat mengalami keadaan berat badan bayi sehingga terjadi gangguan didalam pertumbuhan organ bayi yang dapat menyebabkan terjadi kelainan kongenital. Dari hasil penelitian ini tidak ada hubungan BBL dengan kelainan kongenital, karena mayoritas bayi dilahirkan dengan berat badan matur. Hal ini kemungkinan ibu menjaga asupan gizi ketika awal kehamilan sampai proses akan melahirkan dan memeriksakan kehamilan secara rutin sehingga apabila diketahui ada kandungan nutrisi yang kurang, bisa segera dilakukan intervensi pemberian atau suplemen hingga kekurangan tersebut dapat terpenuhi (Ellyati et al., 2019).

\section{Pembahasan Karakteristik Individu Berdasarkan Cara Lahir}

Penelitian ini didapatkan pasien tidak melakukan persalinan SC yaitu sebanyak 27 orang atau $67,5 \%$, kemudian yang melakukan persalinan SC sebanyak 8 orang atau $20,0 \%$. Sedangkan yang tidak ada data yaitu sebanyak 5 orang atau $12,5 \%$. Pada data yang tidak memiliki informasi terkait cara lahir, maka data tersebut tidak dapat dilakukan analisis lebih lanjut. Berdasarkan penelitian yang sudah dilakukan, faktor risiko cara lahir bayi juga dapat diperhatikan, ibu dengan usia lebih tua (>40 tahun) meningkatkan kemungkinan tindakan operasi seksio sesarea karena merupakan kehamilan risiko tinggi karena kualitas sel telur sudah menurun, kontraksi uterus menurun dan juga dapat timbul penyakit penyerta seperti eklamsia dan diabetes gestasional dimana hal tersebut dapat mengancam mortalitas dan morbiditas tidaknya hanya pada ibu tetapi juga pada janin dan dapat dikaitkan dengan peningkatan resiko kejadian katarak kongenital (Haargaard et al., 2005). 
Cara lahir dengan seksio sesarea dilakukan pada kehamilan resiko tinggi salah satunya adalah kehamilan pada usia tua. Selain itu, faktor lain dilakukannya tindakan seksio sesarea ini adalah usia kehamilan kurang dari 37 minggu kemungkinan organorgan belum sempurna sehingga bila anak lahir kurang bulan kemungkinan bisa menyebabkan terjadi kecacatan kongenital, sedangkan bila usia kehamilan lebih dari 42 minggu fungsi plasenta sudah berkurang sehingga bisa menyebabkan kelainan pada saat bayi lahir (Ellyati, et al.,2019). Dari hasil penelitian ini cara lahir secara seksio sesarea ini memiliki hubugan dengan kejadian kongenital secara umum dan khususnya katarak kongenital. Namun, hubungan ini terjadi secara tidak langsung karena yang diperhatikan yaitu faktor risiko dari ibu. Seringkali katarak kongenital ini juga ditemukan pada bayi prematur dan gangguan sistem saraf seperti retardasi mental, sehingga hal ini dapat menjadi perhatian karena kurangnya kesadaran ibu akan pentingnya melakukan Antenatal Care dan kurangnya fasilitas pemeriksaan akan kelainan bawaan di Indonesia.

\section{Pembahasan Karakteristik Individu Berdasarkan Kelainan Kongenital Lainnya}

Berdasarkan penelitian ini, mayoritas responden masuk dalam kategori ekstraokular yaitu sebanyak 29 orang atau 72,5\%, kemudian responden yang masuk kategori intraokular sebanyak 9 orang atau 22,5\%. Sedangkan responden yang tidak mengalami kelainan lainnya sebanyak 2 orang atau 5,0\%. Temuan penelitan ini mendapatkan bahwa berdasarkan penyebab katarak kongenital ekstraokular, didapatkan 38\% akibat TORCH, 15\% akibat Down Syndrome, 13\% disertai kelainan jantung bawaan, dan $8 \%$ disertai kelainan di bagian tubuh lainnya.

Berdasarkan penelitian yang sudah dilakukan didapatkan frekuensi infeksi rubela adalah sebesar $46,2 \%$ dan penelitian terdahulu memaparkan temuan yang serupa dimana dari 41,3\% pasien yang menderita katarak kongenital, 17,4\% disebabkan oleh infeksi saat kehamilan, 15,2\% disebabkan oleh faktor genetik dan 4,3\% berhubungan dengan Sindroma Down, sementara sebanyak 58,7\% tidak diketahui penyebabnya (Sharma, et $a l ., 2015)$. Berbeda dengan penelitian yang dilakukan pada tahun 2016 dimana didapatkan frekuensi katarak kongenital yang disebabkan oleh infeksi saat kehamilan adalah sebesar $62,07 \%$, faktor genetik sebesar 37,93\%, dan herediter 3,3\%. Infeksi saat kehamilan pada penelitian tersebut kemudian dijabarkan dan didapatkan hasil berupa dominansi dari infeksi rubela (32,5\%) (Naz et al., 2016).

Kelainan ekstraokular kongenital atau kelainan bagian tubuh lainnya, seperti penyakit kulit atau kompleks dan penyakit tulang, yaitu displasia kraniofasial, osteogenesis, dan distrofi kondrosit kongenital dengan kalsifikasi punctate. Katarak kongenital memerlukan tes darah karena hubungan antara katarak kongenital dan diabetes, kalsium dan fosfor (Ilyas, 2006).

Kelainan kongenital pada mata yaitu katarak kongenital yang disertai kelainan mata lainnya. Katarak kongenital biasanya terlihat pada bayi yang lahir dari ibu dengan rubella, galaktosemia, homosistein, diabetes, hipoparatiroidisme, badan inklusi sel raksasa, dan histoplasmosis. Penyakit penyerta lainnya biasanya penyakit keturunan, seperti bola mata kecil, aniridia, defek iris, keratoconus, heterochromia iris, lensa ektopik, 
displasia retina, dan makroplaque kornea. Pada katarak kongenital, komplikasi yang mungkin terjadi adalah makula tidak cukup terangsang. Makula ini tidak akan berkembang sepenuhnya bahkan setelah katarak diangkat, sehingga penglihatan biasanya tidak mencapai 5/5. Ini disebut ambliopia sensorik (ambliopia ex anopsia). Katarak kongenital dapat menyebabkan komplikasi lain, seperti nistagmus dan strabismus (Ilyas, 2010).

\section{Kesimpulan}

Usia pasien katarak kongenital di RSUD Provinsi NTB tahun 2018 sampai 2019 didominasi kelompok usia di bawah 12 bulan yaitu 38 orang atau (95\%). Hal ini menunjukkan bahwa penyakit di deteksi lebih awal sehingga prognosis akan lebih baik pada penglihatan anak. Proporsi anak perempuan dengan katarak kongenital lebih banyak yaitu 21 orang $(52,5 \%)$ dibandingkan anak laki-laki. Katarak kongenital yang mengenai mata paling banyak terjadi pada kedua mata atau bilateral (52,5\%). Sedangkan yang unilateral lebih sedikit dikarenakan sudah mendapat tatalaksana lebih cepat dibandingkan yang bilateral dan prognosis tidak lebih buruk. Wilayah tempat tinggal dominan pasien katarak kongenital paling banyak yaitu di daerah luar Mataram $(92,5 \%)$ dikarenakan fasilitas kesehatan yang kurang lengkap sehingga pasien perlu dirujuk ke fasilitas kesehatan yang lebih memadai untuk mendapatkan tatalaksana sesegera mungkin. Pasien katarak kongenital lebih banyak memiliki riwayat tidak berat badan lahir rendah $(52,5 \%)$ karena mayoritas pasien dilahirkan dengan berat badan matur. Hal ini kemungkinan ibu menjaga asupan gizi dan memeriksa kehamilan secara rutin. Riwayat persalinan pasien katarak kongenital lebih banyak secara tidak sesksio sesarea $(67,5 \%)$ karena SC dilakukan pada kehamilan resiko tinggi salah satunya adalah kehamilan pada usia ibu yang lebih tua dan usia kehamilan yang kurang bulan. Pasien katarak kongenital lebih banyak disertai kelainan kongenital lainnya yang ekstraokular $(72,5 \%)$. 


\section{BIBLIOGRAFI}

Alipour, S. H. M., Rabbani, H., Akhlaghi, M., Dehnavi, A. M., \& Javanmard, S. H. (2012). Analysis of foveal avascular zone for grading of diabetic retinopathy severity based on curvelet transform. Graefe's Archive for Clinical and Experimental Ophthalmology, 250(11), 1607-1614. Google Scholar

Bhatti, T. R., Dott, M., Yoon, P. W., Moore, C. A., Gambrell, D., \& Rasmussen, S. A. (2003). Descriptive epidemiology of infantile cataracts in metropolitan Atlanta, GA, 1968-1998. Archives of Pediatrics \& Adolescent Medicine, 157(4), 341-347. Google Scholar

Dewi, R. F., Harun, Y. Z., \& Sakinah, R. K. (2019). Gambaran Pasien Katarak NonDegeneratif di RSUD Al-Ihsan Provinsi Jawa Barat Tahun 2017. Google Scholar

Ellyati, S., Kusharisupeni, K., \& Sabri, L. (2019). Faktor-Faktor Yang Berhubungan Dengan Kelainan Kongenital Pada Anak di RSPAD Gatot Soebroto. JOURNAL EDUCATIONAL OF NURSING (JEN), 2(2), 37-45. Google Scholar

Finger, R. P., Kupitz, D. G., Fenwick, E., Balasubramaniam, B., Ramani, R. V, Holz, F. G., \& Gilbert, C. E. (2012). The impact of successful cataract surgery on quality of life, household income and social status in South India. Google Scholar

Golozar, A., Chen, Y., Lindsley, K., Rouse, B., Musch, D. C., Lum, F., Hawkins, B. S., \& Li, T. (2018). Identification and description of reliable evidence for 2016 American academy of ophthalmology preferred practice pattern guidelines for cataract in the adult eye. JAMA Ophthalmology, 136(5), 514-523. Google Scholar

Haargaard, B., Wohlfahrt, J., Rosenberg, T., Fledelius, H. C., \& Melbye, M. (2005). Risk factors for idiopathic congenital/infantile cataract. Investigative Ophthalmology \& Visual Science, 46(9), 3067-3073. Google Scholar

HK, K. R. (2013). Katarak Pediatrik: Profil Klinik dan Faktor Determinan Hasil T erapi. Jurnal Kedokteran Brawijaya, 27(3), 178-183. Google Scholar

Ilyas, S. (2006). Katarak (lensa mata keruh). Ke-2. Jakarta: Balai Penerbit FKUI. Google Scholar

Irawan, G. M., Saerang, J. S. M., \& Tongku, Y. (2015). Katarak Pada Anak Di Poliklinik Mata Blu Prof. Dr. Rd Kandou Manado Periode Januari 2011-Desember 2013. ECliniC, 3(1). Google Scholar

Katibeh, M., Eskandari, A., Yaseri, M., Hosseini, S., \& Ziaei, H. (2013). The gender issue in congenital and developmental cataract surgery. Journal of Ophthalmic \& Vision Research, 8(4), 308. Google Scholar

Khotimah, M. E., \& Sutyawan, I. W. E. (n.d.). Karakteristik Penderita Katarak Kongenital Di Divisi Pediatri Oftalmologi Poliklinik Mata Rsup Sanglah Denpasar Periode 1 Januari-31 Desember 2015. Google Scholar 
Lin, D., Chen, J., Lin, Z., Li, X., Wu, X., Long, E., Luo, L., Zhang, B., Chen, H., \& Chen, W. (2015). 10-year overview of the hospital-based prevalence and treatment of congenital cataracts: the CCPMOH experience. PloS One, 10(11), e0142298. Google Scholar

Mwende, J., Bronsard, A., Mosha, M., Bowman, R., Geneau, R., \& Courtright, P. (2005). Delay in presentation to hospital for surgery for congenital and developmental cataract in Tanzania. British Journal of Ophthalmology, 89(11), 1478-1482. Google Scholar

Naz, S., Sharif, S., Badar, H., Rashid, F., Kaleem, A., \& Iqtedar, M. (2016). Incidence of environmental and genetic factors causing congenital cataract in Children of Lahore. The Journal of the Pakistan Medical Association, 66(7), 819-822. Google Scholar

Organization, W. H. (2012). Situation analysis of vision 2020 in the WHO South-East Asia Region. WHO Regional Office for South-East Asia. Google Scholar

Rajavi, Z., Mokhtari, S., Sabbaghi, H., \& Yaseri, M. (2015). Long-term visual outcome of congenital cataract at a Tertiary Referral Center from 2004 to 2014. Journal of Current Ophthalmology, 27(3-4), 103-109. Google Scholar

Reddy, A. K., Ray, R., \& Yen, K. G. (2009). Surgical intervention for traumatic cataracts in children: Epidemiology, complications, and outcomes. Journal of American Association for Pediatric Ophthalmology and Strabismus, 13(2), 170-174. Google Scholar

Ri, K. (2013). Riset kesehatan dasar; RISKESDAS. Jakarta: Balitbang Kemenkes RI, 2013, 110-119. Google Scholar

Sharma, A. K., Shah, D. N., Upadhyay, M. P., Thapa, M., \& Shrestha, G. S. (2014). Demography and etiology of congenital cataract in a tertiary eye centre of Kathmandu, Nepal. Health Renaissance, 12(1), 3-10. Google Scholar

First publication right:

Jurnal Syntax Fusion: Jurnal Nasional Indonesia

This article is licensed under:

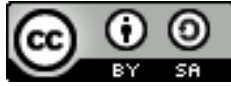

